(C) The Arizona Board of Regents on behalf of the University of Arizona 2020. This is an Open Access article, distributed under the terms of the Creative Commons Attribution licence (http://creativecommons. org/licenses/by/4.0/), which permits unrestricted re-use, distribution, and reproduction in any medium, provided the original work is properly cited.

\title{
THE VALLEY OF JUIGALPA, MAYALES RIVER SUBBASIN MICROREGION (CHONTALES, NICARAGUA) DATE LIST II
}

\author{
Natalia R Donner ${ }^{1 *}$ (D) Alexander Geurds ${ }^{1,2}$ (i) \\ ${ }^{1}$ Faculty of Archaeology, Leiden University, Einsteinweg 2, Leiden 2333 CC, The Netherlands \\ ${ }^{2}$ Institute of Archaeology, University of Oxford, 34-36 Beaumont Street, Oxford, OX1 2PG, United Kingdom
}

\begin{abstract}
The material evidence of human presence in the Chontales region of central Nicaragua spans from $1420 \pm 30 \mathrm{BP}$, or cal AD 554-670 $( \pm 2 \sigma)$ through to the present, as was recently established (Donner and Geurds 2018). This cultural chronology, divided into three main periods, contrasts with the one previously proposed by (Gorin 1990), who defined six different phases from 500 BC through AD 1600. Here, we report on 11 new radiocarbon $\left({ }^{14} \mathrm{C}\right)$ assays, introducing an update to the cultural sequence, consisting of two considerable changes, while also providing further overall strengthening. First, the earliest traces of human groups are now placed at $1645 \pm 25 \mathrm{BP}$, or cal AD 263-536 $( \pm 2 \sigma)$; second, five different periods are established for the research area. A recalibration of Gorin's dates identified their consistency with the results reported here, supporting the new cultural chronology of central Nicaragua. Additionally, this study achieved the complete temporal characterization of Aguas Buenas, the largest pre-colonial archaeological site in Nicaragua.
\end{abstract}

KEYWORDS: AMS radiocarbon dating, Chontales, chronology, Nicaragua, southern Central America.

\section{INTRODUCTION}

Since 2014, the Proyecto Arqueológico Centro de Nicaragua (PACEN), under the direction of Dr. Alexander Geurds, implemented a comprehensive research program to re-define the chronology of the valley of Juigalpa. Located $25 \mathrm{~km}$ northeast of Lake Cocibolca and irrigated by the Mayales river, this valley was previously studied by Franck Gorin (1990) and Dominique Rigat (1992), who established a ceramic sequence comprising six different phases spanning from $500 \mathrm{BC}$ to AD 1600 (Gorin 1990). This ceramic chronology was based on a limited number of four absolute dates and very few excavated contexts. In fact, the two earliest periods in Gorin's proposal, Mayales I (500-200 BC) and Mayales II (200 BC to AD 400), as well as the latest phase (Cuapa, AD 1400-1600) entirely lacked dated radiocarbon $\left({ }^{14} \mathrm{C}\right)$ samples. Therefore, research conducted by PACEN questioned the accepted cultural chronology (Geurds 2013), and produced data that allowed for its reformulation as three different periods ranging from $1420 \pm 30 \mathrm{BP}$, or cal AD 554-670 $( \pm 2 \sigma)($ Beta-457282) to the present (Donner and Geurds 2018).

However, new radiocarbon assays, in combination with a technological approach to ceramic analysis, point to an earlier human presence in the valley-though not as far back in time as Gorin's proposal. These dates were obtained in the context of a systematic high-intensity full-coverage surface survey, which was conducted in a 52 square kilometer area (Arteaga 2017; Donner et al. 2018), together with the excavation of eighteen mounded sites between 2015 and 2016. The point of departure for this study was Aguas Buenas, an archaeological site comprised of 371 human-made stone and sediment mounds, built following different geometric patterns (Geurds and Terpstra 2017), which were hypothesized to correspond to a construction process at several different times over centuries (Auzina 2018). The main objectives of the research program were threefold; to begin with, PACEN aimed at the temporal characterization of Aguas Buenas as well as the other mounded and nonmounded sites documented during the survey. The creation of this research baseline would

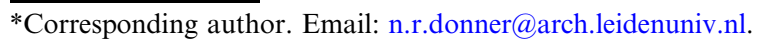




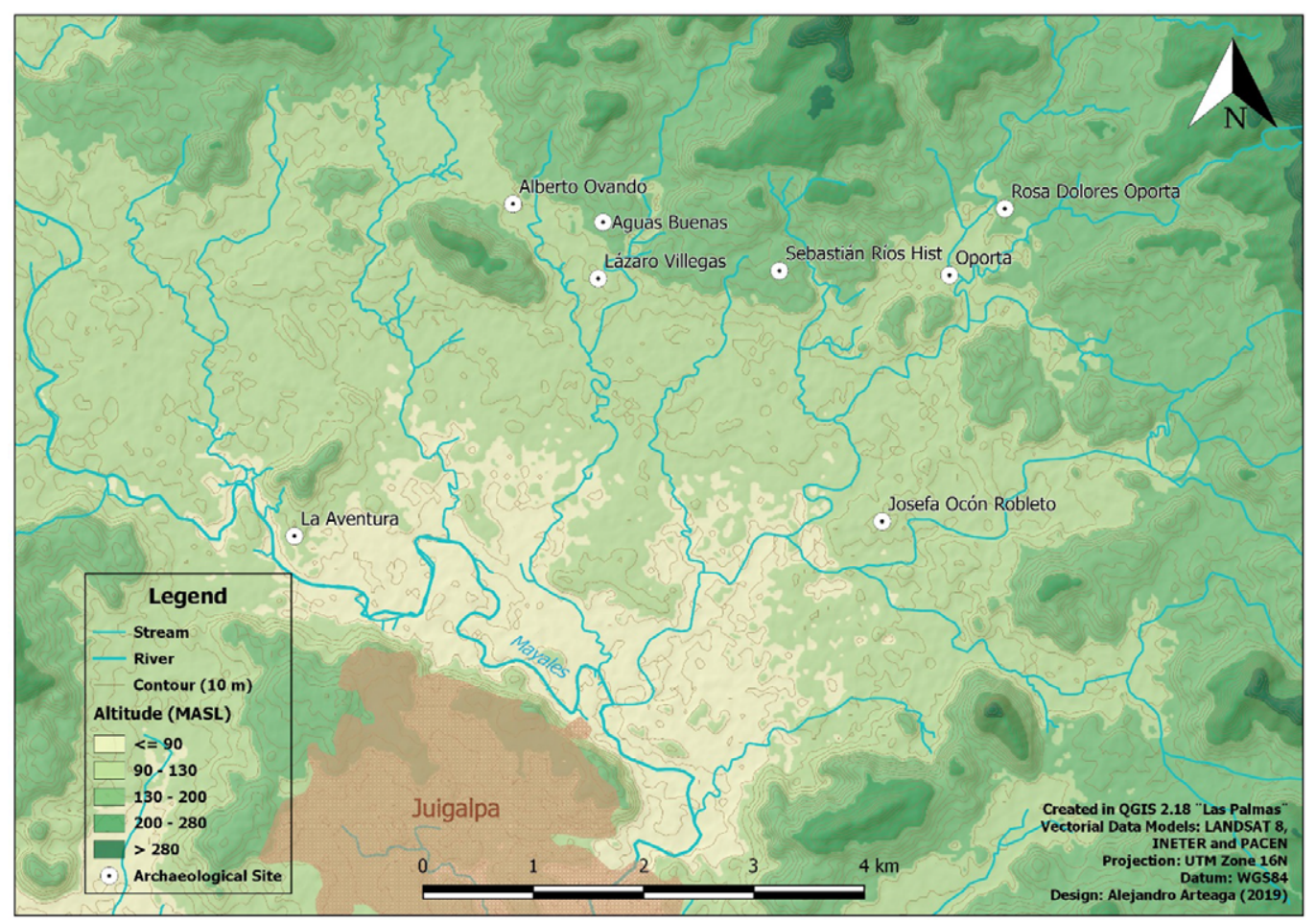

Figure 1 Map of the research area showing the archaeological sites where the new dates were retrieved.

allow for proceeding to the second goal, which consisted in the formulation of better-informed interpretations regarding the history of human occupation in the Mayales River subbasin. Lastly, the new data will help us understand the role of Aguas Buenas as a regional center for the periodic gathering of complex yet horizontally organized communities (Donner et al. 2016; Geurds and Terpstra 2017).

\section{THE NEW DATES}

In total, 11 samples were sent to two different laboratory facilities in order to obtain accelerator mass spectrometry (AMS) radiocarbon ${ }^{14} \mathrm{C}$ ages. These samples consisted of charcoal fragments $(n=5)$, charred seeds $(n=1)$, zooarchaeological remains $(n=3)$, and charred residues deposited on the interior surface of ceramic sherds $(n=2)$. The dated samples were retrieved from stratigraphic excavations conducted at nine different archaeological sites: Aguas Buenas, Alberto Obando, Oporta, Rosa Dolores Oporta, Barillas, Josefa Ocón Robleto, La Aventura, Sebastián Ríos Histórico, and Lázaro Villegas (Figure 1). Data on the majority of these sites will integrally be reported in Donner's doctoral dissertation, but existing information regarding the archaeological characteristics of the microregion can be found in Magnus (1975, 1980), Gorin (1990), Lange et al. (1992), Geurds and Van Broekhoven (Geurds et al. 2009; Geurds and Van Broekhoven 2011), Geurds (2013), Vlaskamp et al. (2014), Arteaga Saucedo (2017), van Dijk (2017), Casale (2017), and Auzina (2018). Calibrations of dates were run using OxCal v4.3.2.2 (Bronk Ramsey 2017), applying the IntCal13 curve (Reimer et al. 2013). Sample pretreatment was done following the protocols described previously (Donner and Geurds 2018). Results are summarized in Table 1 and described below. 
Table 1 New radiocarbon dates for the valley of Juigalpa, Mayales river subbasin.

\begin{tabular}{|c|c|c|c|c|c|c|c|c|}
\hline Lab nr & $\mathrm{Lab}$ & Site & Unit & Layer & $\begin{array}{l}\text { Depth } \\
(\mathrm{cm})\end{array}$ & Material & $\begin{array}{l}{ }^{14} \mathrm{C} \text { dates } \\
\text { (BP) }\end{array}$ & $\begin{array}{l}\delta^{13} \mathrm{C} \\
(\% 0)\end{array}$ \\
\hline UCI-198121 & $\begin{array}{l}\text { W.M. Keck Carbon Cycle } \\
\text { Accelerator Mass Spectrometer }\end{array}$ & $\begin{array}{l}\text { Rosa Dolores } \\
\text { Oporta }\end{array}$ & $1 \mathrm{~B}$ & $\mathrm{XV}$ & $30-40$ & Animal bone & $160 \pm 15$ & -9.3 \\
\hline UCI-198122 & $\begin{array}{l}\text { W.M. Keck Carbon Cycle } \\
\text { Accelerator Mass Spectrometer }\end{array}$ & La Aventura & 1 & II & $20-30$ & Animal bone & $145 \pm 15$ & -8.5 \\
\hline UCI-198123 & $\begin{array}{l}\text { W.M. Keck Carbon Cycle } \\
\text { Accelerator Mass Spectrometer }\end{array}$ & $\begin{array}{l}\text { Sebastian Rios } \\
\text { Historico }\end{array}$ & 1 & IIA & $20-30$ & Animal bone & $100 \pm 15$ & -21.7 \\
\hline Poz-96201 & Poznan Radiocarbon Laboratory & Lázaro Villegas & 1 & II & $10-20$ & Charred seed & $\begin{array}{c}107.17 \pm 0.36 \\
\mathrm{pMC}\end{array}$ & N/A \\
\hline UCI-205413 & $\begin{array}{l}\text { W.M. Keck Carbon Cycle } \\
\text { Accelerator Mass Spectrometer }\end{array}$ & Alberto Obando & 1 & III & $20-30$ & $\begin{array}{l}\text { Charred residue } \\
\text { on sherd }\end{array}$ & $1645 \pm 25$ & N/A \\
\hline UCI-205414 & $\begin{array}{l}\text { W.M. Keck Carbon Cycle } \\
\text { Accelerator Mass Spectrometer }\end{array}$ & Aguas Buenas & 3 & III & $20-30$ & $\begin{array}{l}\text { Charred residue } \\
\text { on sherd }\end{array}$ & $1565 \pm 25$ & N/A \\
\hline UCI-205415 & $\begin{array}{l}\text { W.M. Keck Carbon Cycle } \\
\text { Accelerator Mass Spectrometer }\end{array}$ & Aguas Buenas & 4 & II & $10-20$ & Charcoal & $145 \pm 25$ & N/A \\
\hline UCI-205416 & $\begin{array}{l}\text { W.M. Keck Carbon Cycle } \\
\text { Accelerator Mass Spectrometer }\end{array}$ & Oporta & $1 \mathrm{~A}$ & III & $30-40$ & Charcoal & $175 \pm 25$ & N/A \\
\hline UCI-205417 & $\begin{array}{l}\text { W.M. Keck Carbon Cycle } \\
\text { Accelerator Mass Spectrometer }\end{array}$ & Barillas & $1 \mathrm{~B}$ & IB & $40-50$ & Charcoal & $4240 \pm 280$ & N/A \\
\hline UCI-205437 & $\begin{array}{l}\text { W.M. Keck Carbon Cycle } \\
\text { Accelerator Mass Spectrometer }\end{array}$ & Barillas & $1 \mathrm{~B}$ & III & $40-50$ & Charcoal & $1795 \pm 15$ & N/A \\
\hline UCI-205436 & $\begin{array}{l}\text { W.M. Keck Carbon Cycle } \\
\text { Accelerator Mass Spectrometer }\end{array}$ & $\begin{array}{l}\text { Piedras Grandes } \\
\text { II (JOR) }\end{array}$ & 2 & VII & $70-80$ & Charcoal & $5285 \pm 20$ & N/A \\
\hline
\end{tabular}




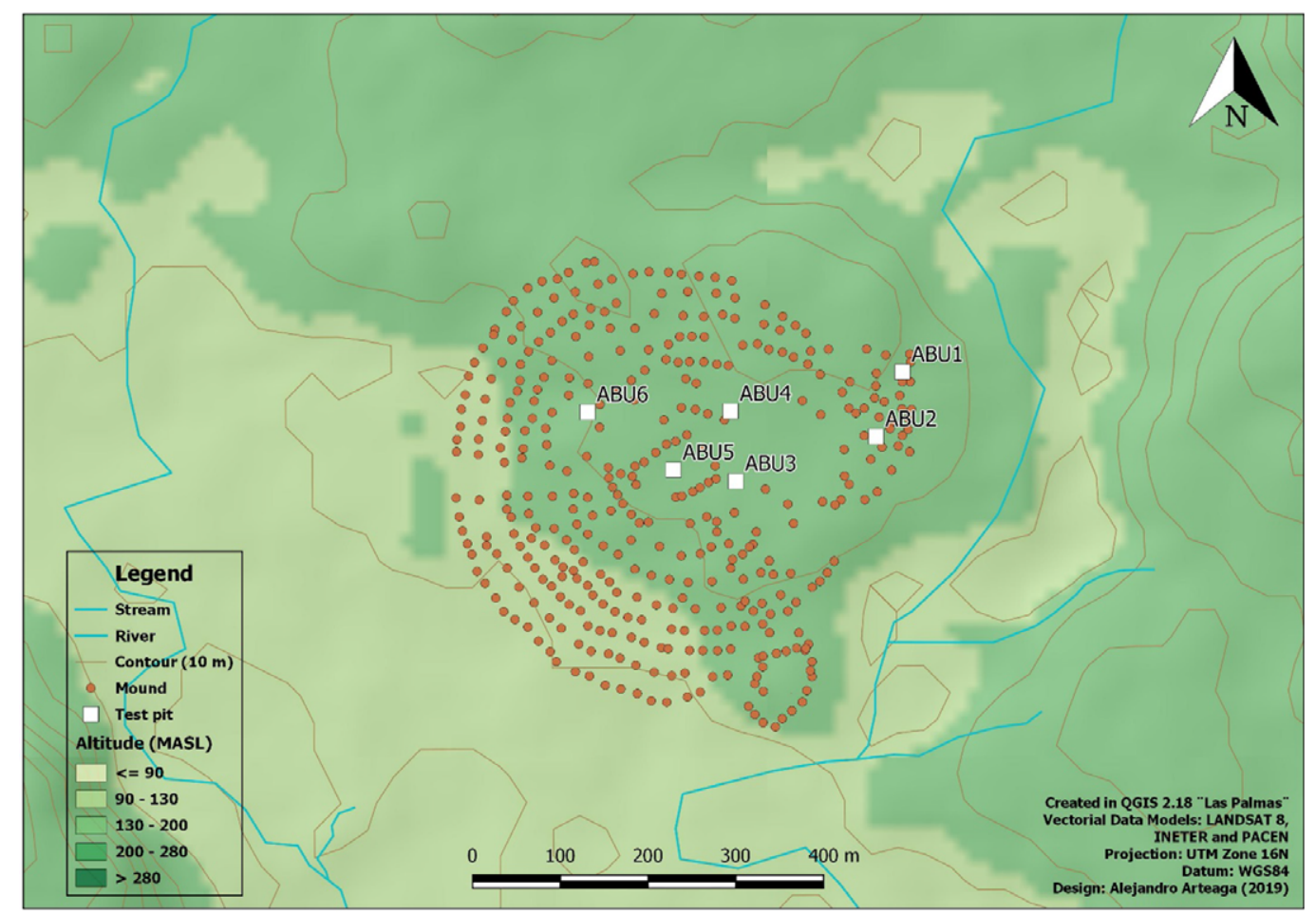

Figure 2 Map of Aguas Buenas showing the location of the different excavation units mentioned in the text.

Samples dated from Aguas Buenas were collected at excavation units ABU3 and ABU4 situated in a non-mounded area (Figure 2) - a section of the site characterized as possibly being one of the earliest construction efforts at the site (Auzina 2018). UCI-205414 consisted of a sherd featuring charred residues on its internal surface, and was retrieved from excavation unit ABU3 at layer III, level $3(20-30 \mathrm{~cm})$, specifically situated at the south section of this moundless section of the site. The sample was dated to $1565 \pm 25 \mathrm{BP}$, or cal AD 404-580 $( \pm 2 \sigma)$. Sample UCI-205415 comprised a charcoal fragment extracted from excavation unit ABU4, stratigraphic unit II, level 2, positioned approximately $30 \mathrm{~m}$ west of mound M272 - the largest mound of the site. The resulting date placed the sample in $145 \pm 25 \mathrm{BP}$, or cal AD 1668-1946 $( \pm 2 \sigma)$. Therefore, the assay was interpreted as originating from charred organic materials the result of historic era burning, as part of agricultural practices. The variability in the dates could result from the de Vries effect (de Vries 1958; Lerman et al. 1970).

Three sites located in the proximity of Aguas Buenas were also sampled for absolute dating. First, Lázaro Villegas, a site featuring 146 mounds built only $150 \mathrm{~m}$ south of Aguas Buenas, was tested through sample Poz-96201, based on a charred seed excavated at ELV1, layer II level 2. This sample was a recent contaminant. Alberto Obando, a site situated $500 \mathrm{~m}$ west of Aguas Buenas, also features a geometrical arrangement of 16 built mound structures, resembling the circular characteristics of Aguas Buenas. Sample UCI-205413, a sherd fragment with charred residue on its internal surface, was collected at EAO1, stratigraphic unit SIII, level 3. Results yielded a date estimated at $1645 \pm 25 \mathrm{BP}$, or cal AD 263-536 $( \pm 2 \sigma)$. Lastly, the site Sebastian Ríos Histórico was selected because it was a very 
particular locality, since in spite of not featuring any visually discernible surface remains, it was the only location within the research area with colonial ceramics at its surface. Furthermore, excavations conducted in 2015 yielded ceramics manufactured following techniques introduced in the area by the Spanish colonizing forces, such as convex moulding, as well as the consumption of introduced European animals butchered according to local practices that involved traditional stone cutting tools (Gill et al. 2019). Sample UCI-198123, part of zooarchaeological materials excavated at ESRH1, layer SllA level 3, produced a date determined to $100 \pm 15 \mathrm{BP}$, or cal AD 1686-1929 $( \pm 2 \sigma)$, which could also be disturbed by the de Vries effect.

Even though the site of La Aventura was very different in appearance from Sebastián Ríos Histórico, the ceramic assemblages of both sites were highly similar. Located at the Mayales river and well over one kilometer west of Aguas Buenas, La Aventura features 22 human-made mounds and it was originally believed to be pre-colonial. However, ceramic technologies and morphologies, as outlined above, challenged this initial assessment. Sample UCI-198122, comprising zooarchaeological materials excavated at ELA1, stratigraphic unit S1l level 3, was tested with results indicating an age corresponding to $145 \pm 15 \mathrm{BP}$, or cal AD 1666-1949 $( \pm 2 \sigma)$. Therefore, absolute dates support the hypothesis formulated by the results of the ceramic analysis.

Also located near the Mayales river, but further north from La Aventura, the site of Barillas was re-tested to confirm the dates previously retrieved (Donner and Geurds 2018). However, the two new samples that were examined yielded contaminated results. UCI-205417 comprised charcoal fragments excavated from EUBI1B stratigraphic unit SIB, level 5, at the foot of mound UBI61. The sample was dated to $4240 \pm 280 \mathrm{BP}$, or cal 3943-1772 BC $( \pm 2 \sigma)$. Since the mound was constructed directly over bedrock, and sedimentation is very shallow (less than $15 \mathrm{~cm}$ ), the sample was interpreted as earlier charred materials, thus not reflecting the age of the mound. UCI-205437 consisted of a charcoal fragment recovered from EUBI1B, stratigraphic unit SIII, level 5. This sample yielded a date of $1795 \pm 15 \mathrm{BP}$, or cal AD 132-327 $( \pm 2 \sigma)$ and was also interpreted as corresponding to materials that were charred before mound construction began. Both dates were collected off-mound and at the same metric level, only a few centimeters from bedrock. These two results contrast the two organic sediment assays previously dated from construction filling excavated at mound UBI61 (Beta-443734), dated to $670 \pm 30 \mathrm{BP}$, or cal AD $1265-1400( \pm 2 \sigma)$, and a posthole trace associated to mound UBI27 (Beta-457276), which yielded $730 \pm 30 \mathrm{BP}$, or cal AD 1216-1388 $( \pm 2 \sigma)$ (Donner et al. 2019; Donner and Geurds 2018). Therefore, these two new samples from Barillas were both interpreted as earlier charred organic materials not indicative of the age of the mounds associated with the excavation units, with no clear relationship to the cultural sequence.

Finally, three samples were dated for sites located near the Carca-Los Copelitos stream, northeast of Aguas Buenas, (Donner and Geurds 2018). Sample UCI-205416 was retrieved at excavation unit EOP1A, stratigraphic unit SIII level 4, and consisted of a charcoal fragment dated to $175 \pm 25 \mathrm{BP}$, or cal AD 1650-1911 $( \pm 1 \sigma)$. The associated context of the sample is a feature consisting of a circle of stones not clearly related to mound OP15, which was constructed before European arrival (Donner and Geurds 2018). Therefore, sample UCI-205416 was interpreted as the result of later activities, which indicates human practices in the valley during colonial times, as indicated also by other dates presented in this paper, and as attested earlier (Donner and Geurds 2018).

UCI-198121 consisted of zooarchaeological materials excavated from ERDO1B stratigraphic unit SXV, level 4. The date obtained was $160 \pm 15 \mathrm{BP}$, or cal AD 1667-1947 $( \pm 2 \sigma)$. Results are comparable to two other samples, Beta- 457277 and Beta-457268, which were previously dated 
for this context (Donner and Geurds 2018). However, the mounds recorded at Rosa Dolores Oporta are still interpreted as pre-colonial, due to the archaeological materials excavated, and earlier dates reported in association to cultural materials (Donner and Geurds 2018). Consequently, the new date could be explained by more recent burning practices possibly related to agricultural activities.

For the Josefa Ocón Robleto site, a charcoal fragment retrieved at JOR2, stratigraphic unit SVII level 8, produced sample UCI-205436, yielding a date of $5285 \pm 20 \mathrm{BP}$, or cal BC 4236-3995 $( \pm 2 \sigma)$. This layer contained a clay spot with some rock fragments, traces of burning activities, as well as ceramic sherds $(n=75)$, burnt clay, and chipped stone artifacts, so the sample was interpreted as contaminated, probably corresponding to older charred materials mixed in an archaeological context.

\section{DISCUSSION}

A reassessment of the chronology proposed by Gorin (1990) is greatly enhanced by the results of the new dates described above. This dataset now comprises of a total of 36 radiocarbon samples, 28 retrieved by the PACEN project, and eight tested by Gorin (1990). Dates were retrieved from 16 different archaeological contexts, including mounded and non-mounded sites, with mostly pre-colonial-but occasionally also colonial materials-found at their surface. The combination of this data, together with spatial analysis (Arteaga 2017; Auzina 2018), ceramics study, and lithic analysis (Jiménez Castillo 2017; Jiménez Castillo et al. 2019; Moreno de Souza et al. 2019) suggests five different moments for the chronology of human presence in the valley of Juigalpa, spanning from $1645 \pm 25 \mathrm{BP}$, or cal AD 263-536 $( \pm 2 \sigma)$ through to the present.

The first period ranges from $1645 \pm 25 \mathrm{BP}(\mathrm{UCI}-205413$, see Table 1), or cal AD $263-536( \pm 2 \sigma)$ to $1260 \pm 30 \mathrm{BP}$, or cal AD 633-882 ( $\pm 2 \sigma)$ (Beta-457266) (Donner and Geurds 2018) (AD 300-900) and includes the sites of Alberto Obando, Aguas Buenas, and Alcides Montiel. All these sites are located near seasonal streams, at the piedmont of the cordillera Amerrisque, characterized by very shallow sedimentation. Mounds were built following geometrical spatial arrangements; construction materials comprised local rocks, quarried bedrock, sediment, ceramic sherds, and chipped stone. Aguas Buenas was the only mounded site that featured petroglyphs as well, both on exposed bedrock (Arteaga 2017; Auziña 2018; Vlaskamp 2012) and in at least one case on a rock used as mound construction material (Vlaskamp et al. 2014:11). A spiral petroglyph, very similar to some of the ones found at Aguas Buenas, was also recorded at Alberto Obando, suggesting that carving bedrock outcrops was a habitual practice. Besides the mounds, which are ubiquitous throughout the valley, material culture both at the surface and in the subsurface was very scarce in sites, indicating possible seasonal practices. A short occupation of the sites could be argued for Alberto Obando and Alcides Montiel, but the Aguas Buenas chronology discards this hypothesis and supports the idea of a gathering place used for several generations (Auzina 2018; Donner et al. 2016; Geurds 2018; Geurds and Terpstra 2017), at least during the first two identified construction episodes. Ceramic imports from Honduras and Pacific Nicaragua are found in very low densities but are present in all the contexts excavated.

The second period ranges from $1020 \pm 40 \mathrm{BP}$, or cal AD 892-1158 $( \pm 2 \sigma)$ through $870 \pm 30 \mathrm{BP}$, or cal AD 1036-1259 ( $\pm 2 \sigma)$ (Donner and Geurds 2018) (AD 900-1250), and is represented in the dataset by sites such as Oporta, Aguas Buenas (non-geometric mound arrangement at the eastern sector), Josefa Ocón Robleto, Sabana Grande, and Roberto Amador. These contexts 
are associated with rich alluvial terraces, which were now available for architectural efforts due to increasingly drier environmental conditions. The valley of Juigalpa experiences an increase in population densities, mounded sites multiply, cover larger areas with a higher amount of manmade structures, and surface materials were found in medium to high densities, suggesting more intense activities. Even though construction techniques show a continuity with previous traditions, sites lack a clear geometric design, indicating a non-planned growth. Open spaces surrounded by mounds are still common and were used for pedestrian circulation and practices related to the preparation of food and beverages. Evidence of clay architecture is clear for this period and even though its presence might predate this time frame, evidence of wattle and daub architecture was found from this phase onwards. Three-dimensional stone sculpture is associated to these contexts; the production of bifacial stone tools and the introduction of obsidian work is characteristic of this period's lithic technologies. In all, excavated contexts, stratigraphic analysis, material culture, and the data provided through absolute dating techniques suggest one single and intense occupation of sites. Ceramic materials from Pacific Nicaragua are especially ubiquitous in specific sites, such as Sabana Grande and Roberto Amador, which are interpreted as a regional focus of intense production practices-including lithics and ceramics, and possibly also products manufactured with perishable materials.

The third period took place between $730 \pm 30 \mathrm{BP}$, or cal AD 1216-1388 $( \pm 2 \sigma)$ and $570 \pm 30 \mathrm{BP}$, or cal AD 1295-1433 $( \pm 2 \sigma)$ (Donner and Geurds 2018) (AD 1250-1450) and includes two excavated contexts: the site of Barillas (Donner and Geurds 2018; Donner et al. 2019) and Rosa Dolores Oporta (Donner and Geurds 2018). Barillas is a mounded site with more than 100 architectural features located on a steep alluvial terrace by the Mayales river. Construction techniques show both continuity and discontinuity with the local tradition, the latter particularly through the inclusion of small river stones as fillings for mounds. The site design combines open and level spaces surrounded by mounds with mortars directly carved on bedrock outcrops, and a single petroglyph. Surface materials were found in medium densities, but in high densities in the subsurface. Stratigraphy and absolute dating point to a single occupation of the site, with no intervals. The ceramic assemblage retrieved at Barillas shows connections to Northeast Honduras, and minimal frequencies of imports from Pacific Nicaragua, in difference to the previous phase. Rosa Dolores Oporta (RDO) is also situated on an alluvial terrace, but alongside the Carca-Los Copelitos stream. The site features 28 human-made mounds, arranged in a geometric configuration forming a $\mathrm{V}$-shaped design as well as a level open area surrounded by large mounds. Material culture was not abundant at the surface and in the subsurface, and ceramics showed technological and aesthetic continuity with sites from the previous period such as Oporta, also located by the Carca-Los Copelitos stream. Stone sculpture and bifacial technology were absent both at Barillas and RDO, while a single obsidian microflake was identified at RDO, which suggests shifting tendencies in networks of interaction and socially learned practices.

The fourth period dates to $145 \pm 15$ BP (UCI-198122, see Table 1), or cal AD 1666-1949 $( \pm 2 \sigma)$ (AD 1650-1900) and features two excavated sites: La Aventura and San Gabino. Both localities are placed on elevated terrains with exceptional visibility to include the entire valley, and even the volcanoes of Ometepe Island. Human-environmental interactions, seen through the lens of provenance studies, point to increasingly more local relations than during precolonial times. These changes in landscape perceptions could also be connected to the presence of the current town of Juigalpa, which was-as it is still today-the regional center where all the dwellers of the valley go to for trade at the market, socialization at the parks and bars, health care, official matters, and feasting. In contrast, communities throughout the valley have 
Table 2 Radiocarbon assays dated by Gorin (1990).

\begin{tabular}{lllclr}
\hline Lab nr & Site & Unit & Depth $(\mathrm{cm} / \mathrm{b} / \mathrm{s})$ & Material & ${ }^{14} \mathrm{C}$ dates $(\mathrm{BP})$ \\
\hline GIF-7228 & La Pachona & SS1 & $1-10$ & Charcoal & $430 \pm 60$ \\
GIF-6894 & El Cobano & SS1 & $10-20$ & Charcoal & $1160 \pm 60$ \\
GIF-6896 & El Cobano & SS2 & $60-70$ & Charcoal & $1290 \pm 70$ \\
GIF-7226 & El Cobano & SS2 & $100-110$ & Charcoal & $1200 \pm 60$ \\
GIF-6895 & El Cobano & SS1 & $40-50$ & Charcoal & $1030 \pm 60$ \\
GIF-6893 & El Tamarindo & SS2 & $10-20 / 20-30$ & Charcoal & $1510 \pm 60$ \\
GIF-7229 & La Pachona & SS1 & $50-60$ & Charcoal & $1100 \pm 60$ \\
GIF-7230 & La Pachona & SS1 & $70-80$ & Charcoal & $750 \pm 60$ \\
\hline
\end{tabular}

decreased in numbers and population seems to concentrate in the modern town. La Aventura featured mound building practices, following construction techniques that show continuity with pre-colonial times; in contrast, San Gabino is a non-mounded site. Material culture suggests that the differences between the sites were connected to their use and function: while La Aventura appears to be used for residential purposes, San Gabino is perhaps a very small household or camp, possibly related to cattle ranching activities. Transformation in ceramic technologies are embodiments of the sociopolitical turmoil of the times. For example, ceramics feature a virtual absence of chromatic decorative techniques, suggesting constrictive Spanish colonial political, economic, and ideological regimes. Also, ceramic manufacturing techniques adopt a new repertoire of bodily gestures, linked to the introduction of the exogenous convex mould, coupled with the coiling technique-the pre-colonial local fashioning signature. Apart from that, griddles become dominant in ceramic assemblages, evincing deep transformations in culinary practices. Interestingly, the production of stone cutting tools is consistent with pre-colonial technologies, and stone tool cut marks on bone material of European-introduced fauna were abundantly excavated at both sites (Gill et al. 2019).

The fifth and last period is the one that intersects with the present, starting around cal AD 1900. During the last century, the valley recovered in numbers, with several hamlets spreading across the landscape. These villages comprise clay houses; separate buildings are common to divide cooking from sleeping practices. Most of the activities take place between kitchen and patio-a flat area surrounded by structures. Gardening, farming, agriculture, and hunting are integrated in daily life. Ceramic technologies are still developed in the valley, and the rejection of the potter's wheel is up until now unanimous. However, the coiling technique has been abandoned, and the fashioning of vessels is now done with a clay mass on a convex mold. Distribution of pottery centers around the Juigalpa market and other nearby towns, but the replacement of clay vessels by materials such as plastic and aluminium are threatening the continuity of the ceramic production.

\section{CONCLUSION}

This new chronology does not necessarily contradict the previous one (Gorin 1990), since recalibration of assays dated in the 1980s with IntCal13 match the sequence proposed on this paper. The raw radiocarbon data from the eight samples retrieved by Gorin (1990:259) (Table 2) were recalibrated using the same software packages applied to the samples analyzed in this paper. Results (Figure 3) point to a coherence and not a 


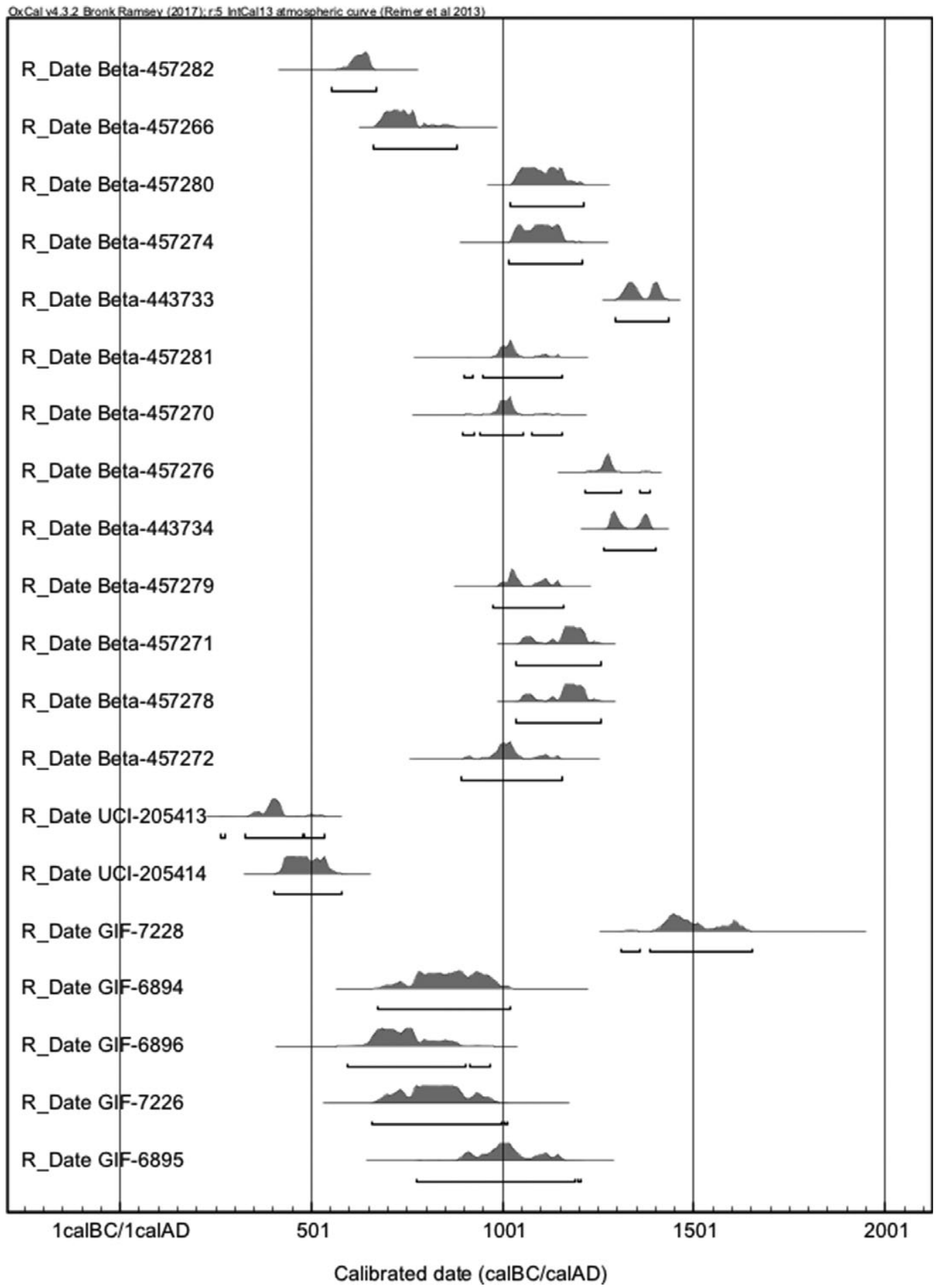

Figure 3 Recalibration of the dates retrieved by Gorin (1990) show coherence between his results and the assays analyzed by PACEN. The figure graphically presents the probability distributions of the samples examined by Donner and Geurds (2018)—all coded starting with the word Beta-as well as the ones introduced in this article — codes starting with UCI - and previously by Gorin (1990) — the last five in the graph, with codes starting with the letters GIF. Samples that dated later than $1500 \mathrm{CE}$ were not included to focus on the periods in which the results of both research projects match. 
discrepancy with Gorin's sequence, with his dates demonstrating a span from $1510 \pm 60 \mathrm{BP}$, or cal AD 352-668 $( \pm 2 \sigma)(\mathrm{GIF}-6893)$ to $430 \pm 60 \mathrm{BP}$, or cal AD 1312-1652 $( \pm 2 \sigma)(\mathrm{GIF}-7228)$. La Pachona spans from $1100 \pm 60 \mathrm{BP}$, or cal AD 689-1012 ( $\pm 2 \sigma)(\mathrm{GIF}-7229)$ to $430 \pm 60 \mathrm{BP}$, or cal AD 1312-1652 $( \pm 2 \sigma)$ (GIF-7228), which coincides with the preliminary assessment made for its ceramics. El Cóbano yielded dates between $1290 \pm 60 \mathrm{BP}$, or cal AD 595-968 $( \pm 2 \sigma)($ GIF-6896) and $1030 \pm 60 \mathrm{BP}$, or 775-1205 $( \pm 2 \sigma)(\mathrm{GIF}-6895)$, so it could partially overlap in time with the construction of the mounds forming arches at Aguas Buenas (see Figure 2), and with our second period. Finally, El Tamarindo yielded a date between cal AD 352 and $668( \pm 2 \sigma)$ (GIF-6893), so it was contemporary with the earliest stages of Aguas Buenas.

The site of Aguas Buenas features material evidence corresponding to four of the periods established in this updated chronology, and the "gaps" could be related to sample bias. The new chronology then proposes that Aguas Buenas's architectural features were constructed in a series of building efforts over centuries, starting around cal AD 400 with its rectangular central section, with practices also taking place at the non-mounded area located immediately to the east. Then, the concentric arches were completed around cal AD 600, with a final stage comprising the non-geometric eastern part of the site AD 900 and 1250. The chronology of the southeast portion of the site and the modifications done to the arches identified by Auzina (2018) is still pending characterization, and additional excavations are necessary in order to elucidate the complete sequence of the site. However, we can now confidently establish that the first construction efforts took place as far back as cal AD 400 and the last mounds were probably built sometime between cal AD 900 and 1250. Human practices in Aguas Buenas possibly took place before the beginning of the construction project and certainly continued-as evidenced by sample UCI-205415-in recent history, and even today, when the terrain is owned by families who live among the mounds, as well as engage with the site through agricultural and cattle ranching practices. The history of Aguas Buenas, it seems then, is deeply connected with the trajectories of human communities in the valley of Juigalpa.

\section{ACKNOWLEDGMENTS}

We would like to thank Alejandro Arteaga Saucedo, who designed the maps for this contribution. We also gratefully acknowledge all the PACEN members for their collaboration in the excavations and their help for taking the samples in the field. Special thanks to Erica van Hees (Faculty of Archaeology, Leiden University) and Lucy Gill (Department of Anthropology, University of California, Berkeley), who aided in the selection of the archaeobotanical and zooarchaeological samples. Additionally, we express our gratitude to the Nicaraguan Institute of Culture, and in particular its co-director Luis Morales Alonso and the director of the Archaeology Directorate, Ivonne del Carmen Miranda Tapia, for their continued support of the project and issuing the permits to export samples. We are also indebted to the staff of the W.M. Keck Carbon Cycle Accelerator Mass Spectrometer and the Poznańskie Laboratorium Radioweglowe for running the dates. This research was made possible by the VIDI grant (PI A. Geurds) "Networked practices of contact: Cultural identity at the Late Prehistoric settlement of Aguas Buenas, Nicaragua, AD 500-1522”, of the Netherlands Organisation for Scientific Research (NWO). Thanks to the annonymous reviewers whose comments helped improve the manuscript. This article is dedicated to the memory of don Gustavo Villanueva Molina (1930-2019). 


\section{REFERENCES}

Arteaga A. 2017. Reconstruccion del paisaje social prehispanico en la microcuenca del rio Mayales, Chontales, Nicaragua [unpublished MA thesis]. Mexico City: Universidad Nacional Autonoma de Mexico.

Auziņa D. 2018. Monumentality by communities. Mapping the spatial logic of the pre-Hispanic site Aguas Buenas (AD 400-1600) in Central Nicaragua [unpublished MA thesis]. Leiden: Faculty of Archaeology (Leiden University).

Bronk Ramsey C. 2017. Methods for summarizing radiocarbon datasets. Radiocarbon 59(6): 1809-1833. doi: 10.1017/RDC.2017.108.

Casale S. 2017. Pre-Hispanic clay roads. Evaluation and interpretation of ceramic production and raw clay procurements in the Rio Mayales Subbasin, Chontales, Nicaragua [unpublished MA thesis]. Leiden: Faculty of Archaeology (Leiden University).

de Vries H. 1958. Variation in the concentration of radiocarbon with time and location on earth. Proc. Koninkl. Nederl. Akad. Wetenschappen 61: 94-102.

Donner NR, Arteaga A, Geurds A, van Dijk K. 2018. Caracterización inicial de los sitios arqueológicos en la subcuenca del río Mayales, Departamento de Chontales, Nicaragua. Cuadernos de Antropología Enero-Junio 28(1):1-26. doi: 10. 15517/CAT.V28I1.32358.

Donner NR, Casale S, Braekmans D, Geurds A. 2016. Traditions of monumentality as a collective endeavour: the Case of Aguas Buenas, Chontales, Nicaragua. Paper presented at the Ceramic Petrology Meeting, Faculty of Archaeology, Leiden University.

Donner NR, Casale S, Braekmans D, Geurds A. 2019. Ceramic comales at the Barillas site (cal 1255-1390 CE), central Nicaragua: Defining a local technical tradition of griddle manufacture. Journal of Archaeological Science: Reports 24:829-842. doi: 10.1016/j.jasrep.2019.02.037.

Donner NR, Geurds A. 2018. The valley of juigalpa, mayales river subbasin microregion (Chontales, Nicaragua) date list I. Radiocarbon 60(2): 717-726. doi: 10.1017/RDC.2017.147.

Geurds A. 2013. The Cuapa Complex: A note on the last pre-Hispanic ceramic period from Central Nicaragua. Mexicon Zeitschrift für Mesoamerikaforschung 35(6):148-151.

Geurds A. 2018. Collaborative effort and bonding practices: Organizing Aguas Buenas in the Rio Mayales subbasin, Nicaragua. Paper presented at the ICA conference, Salamanca, Spain.

Geurds A, Terpstra D. 2017. Circular reasoning in mound building? Large- scale planned construction patterns at the Aguas Buenas site (A.D. 400-1525). In: Benfer AK, editor. War \& peace: Conflict and resolution in archaeology.
Proceedings of the 45th Annual Chacmool Archaeology Conference. University of Calgary, Alberta: Chacmool Archaeological Association. p 47-59.

Geurds A, Van Broekhoven L. 2011. Chontales en su sentido etnico. Mi Museo y Vos 16:6-10.

Geurds A, Zambrana Fernandez J, Van Broekhoven L. 2009. La historia y el patrimonio en el departamento de Chontales. Mi Museo y Vos 8:4-7.

Gill L, Donner NR, Geurds A. 2019. Human-animal entanglements in the valley of Juigalpa, central Nicaragua. Manuscript in preparation.

Gorin F. 1990. Archéologie de Chontales, Nicaragua. Volume 1 [unpublished $\mathrm{PhD}$ dissertation]. Paris: Université de Paris I (Panthéon-Sorbonne).

Jiménez Castillo S. 2017. El yacimiento de Sabana Grande: aproximación tecno-tipológica a la industria bifacial [unpublished BA thesis]. Barcelona: Universidad de Barcelona.

Jiménez Castillo S, Donner NR, Geurds A. 2019. Lithic technologies in the valley of Juigalpa, central Nicaragua. Manuscript in preparation.

Lange F, Sheets P, Martínez A, Abel-Vidor S. 1992. The Archaeology of Pacific Nicaragua, 1st edition. Albuquerque (NM): University of New Mexico Press.

Lerman J, Mook W, Vogel J. $1970 .{ }^{14} \mathrm{C}$ in treerings from different localities. In: Olsson I, editor. Radiocarbon variations and absolute chronology: Proceedings of the Twelfth Nobel Symposium held at the Institute of Physics at Uppsala University. Stockholm: Almquist and Wiksell.

Magnus R. 1975. Present archaeological research in Chontales, Nicaragua: Its Implications for the prehistory of lower Central America. Managua, Nicaragua: Banco Central.

Magnus R. 1980. La secuencia ceramica de la costa Atlantica y la zona central de Nicaragua. Boletín Nicaragüense de Bibliografía y Documentación: 35-36, 52-61.

Moreno de Souza JC, Jimenez Castillo S, Donner NR, Geurds A. 2019. Chontales cores: A Late Holocene microdebitage method from central Nicaragua. Manuscript in preparation.

Reimer PJ, Bard E, Bayliss A, Beck JW, Blackwell PG, Bronk Ramsey C, Buck C, Cheng H, Edwards RL, Friedrich M, Grootes PM, Guilderson TP, Haflidason H, Hajdas I, Hatté C, Heaton TJ, Hoffmann DL, Hogg AG, Hughen KA, Kaiser KF, Kromer B, Manning SW, Niu M, Reimer RW, Richards DA, Scott EM, Southon JR, Staff RA, Turney CSM, van der Plicht J. 2013. IntCal13 and Marine13 radiocarbon age calibration curves $0-50,000$ years cal BP. Radiocarbon 55(4):1869-1887. doi: 10.2458/ azu_js_rc.55.16947. 
Rigat D. 1992. Préhistoire au Nicaragua: Région Juigalpa, Département de Chontales [unpublished $\mathrm{PhD}$ dissertation]. Paris: Université de Paris I (Panthéon-Sorbonne).

van Dijk K. 2017. Mounds in context. Environmental variables and pre-Columbian mound distribution in the Mayaler river Subbasin, Chontales, Nicaragua [unpublished BA thesis]. Leiden: Faculty of Archaeology (Leiden University).
Vlaskamp R. 2012. Rock solid: Rock art analysis and documenting at Aguas Buenas (AD 400-1600), Nicaragua [unpublished BA thesis]. Leiden: Faculty of Archaeology (Leiden University).

Vlaskamp R, Geurds A, Jansen R. 2014. Reporte de las investigaciones arqueológicas entre 2011-2014 en el sitio prehispánico de Aguas Buenas, Chontales, Nicaragua. Mi Museo y Vos 29:6-12. 